\title{
CHAEREAS REVISITED. RHETORICAL CONTROL IN CHARITON'S 'IDEAL' NOVEL CALLIRHOE
}

\section{INTRODUCTION}

In ancient novel scholarship, the distinction between the ideal Greek novel and its comic-realistic Latin counterpart has been, and still is, highly influential. It originates with R. Heinze's thesis that Petronius' Satyricon develops from a literary genre parodying idealistic features in the Greek novels. ${ }^{1}$ Despite the contributions of scholars warning against applying this dichotomy too rigidly, ${ }^{2}$ the distinction remains a commonly accepted tool to classify novelistic literature. ${ }^{3}$ In this paper I will focus on the characterization of the male protagonist in Chariton's Callirhoe, the oldest of the so-called ideal novels. ${ }^{4}$ My reading of this character will suggest that Chariton's position within the ideal genre should be reassessed, and that consequently the overall distinction between ideal and realistic novels is a generalization that does not take into account the actual complexity of one of the oldest representatives of the genre.

The distinction between ideal Greek and realistic Latin novelistic literature is largely informed by the divergent depiction of character in both sub-genres. Whereas the Latin novel adopts realistic and sexually explicit character portrayal, scholars have underlined the idealizing aspects in the characterization of protagonists in the Greek novel. Their beauty invests them with a godlike appearance, and their nobility ( $\left.\epsilon \dot{v} \gamma \epsilon^{\prime} v \iota \iota \alpha\right)$ generates loftiness of character that sharply distinguishes them from other, less noble, characters in the story. ${ }^{5}$ Scholars have emphasized the unreal atmosphere surrounding this characterization. ${ }^{6}$ E. Rohde's view that the protagonists in the Greek novel are 'seelenlose Gestalten' and 'Gliederpuppen', invested with a 'leere und

1 R. Heinze, 'Petron under der griechische Roman', Hermes 34 (1899), 494-519.

2 Cf., e.g., F. Wehrli, 'Einheit und Vorgeschichte der griechisch-römischen Romanliteratur', MH 22 (1965), 133-54. Recently, A. Barchiesi, 'Romanzo greco, romanzo latino: problemi e prospettive della ricerca attuale', in L. Graverini, W. Keulen and A. Barchiesi, Il romanzo antico. Forme, testi, problemi (Rome, 2006), 193-218 points to a number of less idealistic elements in various Greek novels.

3 Cf., e.g., N. Holzberg, Der antike Roman. Eine Einführung (Darmstadt, 2006³), 59-138, classifying the texts under the headings of 'Der idealisierende Roman: Ältere Texte' (59-79), 'Der komisch-realistische Roman' (80-111) and 'Der idealisierende Roman: Jüngere Texte' (112-38).

${ }^{4}$ Callirhoe was probably written within one or two decades either side of A.D. 50. This view is defended by B.P. Reardon, 'Chariton', in G. Schmeling (ed.), The Novel in the Ancient World (Leiden, 1996), 309-35, at 317, and E.L. Bowie, 'The chronology of the earlier Greek novels since B.E. Perry: revisions and precisions', Ancient Narrative 2 (2002), 47-63, at 57, who dates Chariton between A.D. 41 and 62. For an overview of different accounts of the dating of Chariton, see S.D. Smith, Greek Identity and the Athenian Past in Chariton: The Romance of Empire (Groningen, 2007), 2, n. 4.

5 E.g. F. Napolitano, 'Leucippe nel Romanzo di Achille Tazio', Annali della Facoltà di Lettere e Filosofia della Università di Napoli 26 (1983-4), 85-101, at 86: characters are 'fortemente stilizzati' because of a 'forte processo di idealizzazione' (with reference made to the beauty of the protagonists).

6 E.g. D. Del Corno, 'Anzia e le altre', Atti del II Convegno Internazionale. La donna nel mondo antico (Turin, 1989), 75-84, at 84: 'Certo, la protagonista del romanzo greco è una figura ideale, per non dire irreale: come già la stessa eccezionalità dei suoi connotati fisici e anagrafici esplicitamente ammette'. 
leblose Idealität', has never been substantially contested. ${ }^{7}$ Scholars who point to the presence of some psychological realism in the protagonists' characterization do not go any further than making short, occasional suggestions. A. Lesky, for example, conjectures that the influence of rhetorical school curricula on the novelists 'must have led, at least for the more gifted, to a greater profundity of the intellectual processes and to a more refined elaboration of psychological details', ${ }^{8}$ but he does not develop this suggestion in any detail. Common opinion still has it that realistic character depiction is to be looked for (to a certain extent, at least) primarily in the characterization of minor characters. ${ }^{9}$

Yet, it has often been pointed out that psychologically realistic detail plays a more important role in Chariton's novel than in the other extant novels. ${ }^{10}$ It is telling, however, that only the characterization of the minor characters and occasionally of Callirhoe have been adduced to support this thesis. ${ }^{11}$ The characterization of Chariton's male protagonist Chaereas, on the other hand, has been largely neglected. According to J. Helms, the author of the only systematic study on characterization in Chariton up to now, it is not even worthwhile to look for any realistic detail in Chaereas' characterization in the first place: 'There is ... such a dearth of realistic detail that a discussion of realism in the case of Chaereas would be unprofitable and, therefore, it has not been considered further'. ${ }^{12}$

Long before Helms, J. Dunlop wrote in his History of Fiction that Chariton was the first writer of romance who succeeded in depicting an 'interesting' male character. ${ }^{13}$ Since Dunlop assumed, like Rohde later, that Chariton was the latest of all Greek novelists, Chariton is, in his view, not only the first, but also the only novelist applying psychological characterization. Significantly, however, Dunlop's statement does not refer to Chariton's protagonist Chaereas, but to the Milesian antagonist Dionysius.

The limited attention that Chaereas' characterization has received centres primarily upon his assimilation with pre-existing character types. It has been pointed out, for example, that Chaereas is associated, merely by his name, with the character type of the adulescens, often bearing the same name in New Comedy. ${ }^{14}$ This character type is hot-tempered and passionate, and Chaereas' name might be read as an implicit prolepsis of his uncontrolled outburst in the first book of the novel. Furthermore, Chaereas' assimilation with epic and tragic heroes and the inversions of and divergences from these paradigms have also received some attention. ${ }^{15}$ So far, however,

${ }^{7}$ E. Rohde, Der griechische Roman und seine Vorläufer (Leipzig, 1914), 476-7.

8 A. Lesky, A History of Greek Literature (trans. J. Willis and C. de Heer; orig. Geschichte der griechischen Literatur [Munich, 1963²]) (London, 1966), 859.

${ }^{9}$ Cf. B.P. Reardon, The Form of Greek Romance (Princeton, 1991), 26; Holzberg (n. 3), 63.

${ }^{10}$ G. Schmeling, Chariton (New York, 1974), 157-8; A. Billault, 'Aspects du roman de Chariton', IL 33 (1981), 205-11, at 206.

${ }^{11}$ Cf. Rohde (n. 7), 430; B.P. Reardon, 'Theme, structure and narrative in Chariton', YClS 27 (1982), 1-27, at 13. J. Helms, Character Portrayal in the Romance of Chariton (The Hague/Paris, 1966), 127-46 includes a small chapter on 'realism in small details'. Although Helms credits Chariton's heroine with a couple of individual traits accentuated by the 'use of realistic and picturesque details' (129), he traces realism 'especially in the portrayal of the minor dramatis personae' (128). On psychologically realistic features in Callirhoe's characterization, cf. K. De Temmerman, 'Blushing beauty. Characterizing blushes in Chariton's Callirhoe', Mnemosyne 60.2 (2007), 235-52.

${ }^{12}$ Helms (n. 11), 129.

13 J. Dunlop, History of Fiction (London, 1814), vol. 1, 59.

${ }^{14}$ Cf., e.g., Bowie (n. 4), 47-63, at 55.

15 Schmeling (n. 10), 130-59 maps out Chaereas' characterization against the background of 
only S. Smith's recent exploration of similarities between Chaereas and Alcibiades has substantially problematized the widely held idealizing view of Chariton's protagonists in general, and of Chaereas in particular. This article further corroborates such problematization.

A feature of Chaereas' characterization that has triggered disapproval among students of the genre is his sudden character shift in the seventh book. In the first six books of the eight-book novel, Chaereas is characterized by passive behaviour that sharply contrasts him with the resourceful heroine Callirhoe. Unlike her, Chaereas hardly ever undertakes any action to resolve his problems and spends most of his time lamenting his separation from his wife. In the seventh book, however, his behaviour changes dramatically: following the advice of his friend Polycharmus, he joins the Egyptian army revolting against the Persian king Artaxerxes, and turns out to be a brilliant soldier. He succeeds in occupying the impregnable city of Tyre, and in less than no time he is the admiral of the whole Egyptian fleet. Scholars have criticized the improbability and inconsistency of this character shift. Rohde, for example, articulates the following complaint: 'man verwundert sich, am Schluß des Ganzen den bis dahin so wenig energischen Chaereas urplötzlich zum siegreich handelnden und herrschenden Kriegshelden sich umwandeln zu sehen. Solche Tatkraft stimmt wenig zu seiner sonstigen Weichlichkeit, zu der Weichlichkeit der ganzen Erzählung und fast aller Personen derselben'. ${ }^{16}$

R. Balot argues that Chaereas' character shift essentially revolves around the thematization of martial valour as the fulfillment of 'the central virtues appropriate to his gender, training, and elite status'. ${ }^{17}$ In his view, Chaereas' military excellence signposts 'a turnabout in which Chaereas becomes the man he is required to be if he is to win back Callirhoe and begin to recreate his marriage' (157). D. Scourfield rightly adds that Chaereas' gradually developing ability to learn how to control and to utter his anger appropriately represents the young man's personal growth towards a 'full adult-male status'. ${ }^{18}$ Indeed, Chaereas' initial anger, triggered by the false suspicion about his wife's infidelity, persists throughout the entire novel. What makes Chariton's protagonist an adult man is not a renunciation of anger but the ability to control this emotion and not be driven to impulsive and irrational behaviour by it. In this paper I want to draw attention to a new (and yet related) dimension of Chaereas' character shift. I will put forward two arguments. First, I propose that, next to military excellence and the acquisition of self-control, the acquisition of control over other characters is an equally important feature of Chaereas' character shift. ${ }^{19}$ In this connection, I take into account S. Smith's recent, politically oriented reading of Chaereas as the rising star in the Syracusan political firmament who is about to

traditional concepts of heroism in epic and tragedy (incarnated in Achilles and Ajax respectively). On Chaereas' assimilation with epic paradigms, see D. Konstan, 'La rappresentazione dei rapporti erotici nel romanzo greco', MD 19 (1987), 9-27, at 9-11 and D. Konstan, Sexual Symmetry. Love in the Ancient Novel and Related Genres (Princeton, 1994), 16-17. For a recent overview of scholarship on Chaereas, see Smith (n. 4), 19-22.

${ }^{16}$ Rohde (n. 7), 527.

17 R.K. Balot, 'Foucault, Chariton, and the masculine self', Helios 25.2 (1998), 139-62, at 156.

${ }_{18}$ D. Scourfield, 'Anger and gender in Chariton's Chaereas and Callirhoe', in S.M. Braund and G.W. Most (edd.), Ancient Anger. Perspectives from Homer to Galen (Cambridge, 2003), 163-84.

${ }^{19}$ Smith (n. 4), 83-4 has concisely touched upon the connection between self-control and control over other characters as an element underlying the characterization of Chariton's two minor characters Dionysius and Artaxerxes. My reading of Chariton's protagonist develops this point and emphasizes its thematic centrality in the novel. 
displace Hermocrates soon after his return to Syracuse..$^{20}$ My paper points out that, along Chaereas' road towards political power, the establishment of control over (and even manipulation of) other characters is an issue of primary importance. Secondly, and consequently, I argue that my observations challenge the widely held view that character depiction of protagonists in the ancient Greek novel is invariably idealistic.

\section{CHAEREAS AND RHETORICAL CONTROL}

The concept of control discussed in this paper is of a rhetorical nature, comprising the protagonist's ability to influence the behaviour of other characters through speech. In the heyday of the ancient Greek novels, the construction of speech in character (êthopoiia) was one of the so-called progymnasmata, preliminary rhetorical school exercises in writing and composition. These progymnasmata, discussed by, among others, Aelius Theon, Ps.-Hermogenes, Aphthonius and Nicolaus, ${ }^{21}$ were an essential part of rhetorical education in antiquity from at least the first century B.C. onwards ${ }^{22}$ and undeniably influenced imperial literature. ${ }^{23}$ Therefore, it is more than likely that both writer and reader of narrative will have considered speech an important index of character. On a more general note, M. Gleason has extensively discussed rhetorical performance as a crucial tool in achieving and displaying manliness in the first centuries A.D. ${ }^{24}$ Within this framework, this article sets out to interpret Chaereas' rhetorical performance and self-presentation as an index of his growth towards male adulthood.

The distribution of Chaereas' speeches, including public speeches and private conversations, around his character shift is significant. In the first six books (before the character shift, that is), Chaereas speaks in public only twice. The last two books feature no less than seven such speeches. Let me first discuss the speeches before his character shift. Chaereas' first public speech is his $\pi \rho \sigma \sigma \alpha \gamma \gamma \epsilon \lambda_{i}^{\prime} \alpha$ or self-accusation after the supposed murder of Callirhoe in Book 1 (1.5.4-5). The primary narrator highlights that Chaereas adduces none of the arguments in his defence. Instead, he asks the jury to be sentenced to death for murdering the daughter of Syracuse's first citizen Hermocrates. Moreover, he insists on being denied burial after his death, comparing his crime to temple robbery and parricide. S. Smith rightly argues that the equation between Chaereas' emotional expression and the sincerity of his inner state

${ }^{20}$ Smith (n. 4), 190-1. See also S. Lalanne, Une éducation grecque: rites de passage et construction des genres dans le roman grec ancien (Paris, 2006), 158 for a short depiction of Chaereas as the new Hermocrates.

${ }^{21}$ All treatises are edited by L. Spengel (ed.), Rhetores Graeci (Leipzig, 1854 and 1856), vols 2 and 3. A more recent edition of Theon is M. Patillon (ed.), Aelius Théon. Progymnasmata (Paris, 1997).

${ }_{22}$ Cf. G. Kennedy, Classical Rhetoric and its Christian and Secular Tradition from Ancient to Modern Times (Chapel Hill / London, 1999), 27.

${ }^{23}$ Cf. A. Cizek, Imitatio et tractatio. Die literarisch-rhetorischen Grundlagen der Nachahmung in Antike und Mittelalter (Tübingen, 1994), 236-41; H. Cichocka, 'Progymnasma as a literary form', SIFC 10 (1992), 991-1000; G. Kennedy, Greek Rhetoric under Christian Emperors (Princeton, 1983), 53 and 143. Theon, Prog. 70.24-30 Spengel 2 explicitly underlines the impor-

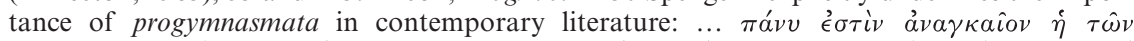

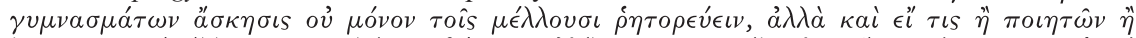

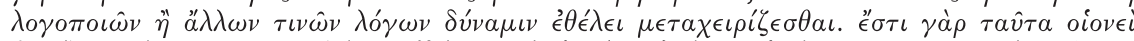

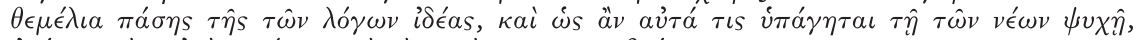

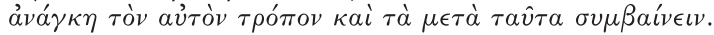

${ }^{24}$ M. Gleason, Making Men. Sophists and Self-Presentation in Ancient Rome (Princeton, 1995), xx-xxix and 131-68. 
in this speech signposts neutralization of the power of rhetoric. ${ }^{25}$ This neutralization is, I think, equally fleshed out by the fact that Chaereas' speech in the end does not generate the envisaged effect: the audience forgets about the dead general's daughter

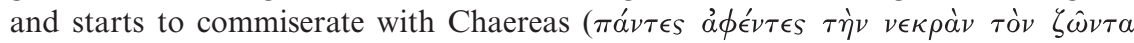
$\left.\dot{\epsilon}^{\prime} \epsilon^{\prime} \nu \theta_{0} v \nu, 1.5 .6\right)$. When the jury finally acquits Chaereas, the protagonist himself, unhappy with this decision, thinks of possible ways to kill himself ( $\epsilon \pi \epsilon \theta \dot{v} \mu \epsilon \iota$ $\theta \alpha \nu a ́ \tau o v$

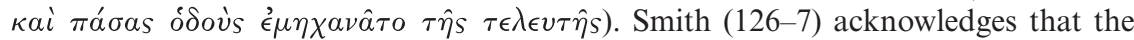
power of rhetoric, absent from this speech, is 'amply demonstrated elsewhere' in Chariton's novel. He specifically refers to other male characters, such as Dionysius and Artaxerxes, who, unlike Chaereas in this episode, rationalize personal emotions by means of subtle, rhetorical self-fashioning. As I will point out, Chaereas' own rhetorical self-fashioning later in the story will also demonstrate the importance of the power of rhetoric in this novel.

Chaereas' second public speech is found in Book 3 (3.4.5-6 and 3.4.15), when he returns from the search for Callirhoe in the Ionian Sea and brings Theron to Syracuse. Framing this speech, the primary narrator takes pains to indicate that Chaereas has trouble assuming the self-control that might be expected of an orator addressing his audience. I refer to the physical details preceding the quotation of his speech ( $\dot{\omega} \chi \rho o$ s,

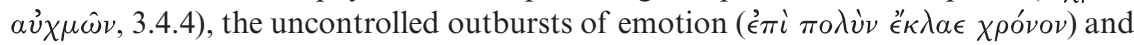
the inability to address the public verbally ( $\phi \theta \dot{\epsilon} \gamma \xi \alpha \sigma \theta \alpha \iota \theta \epsilon^{\prime} \lambda \omega \nu$ ov่k $\left.\eta^{\prime} \delta \dot{v} \nu \alpha \tau o, 3.4 .4\right)$ or

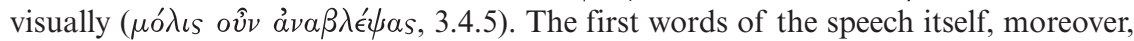
are in line with the overall picture drawn by the narrator. Chaereas says that it is not

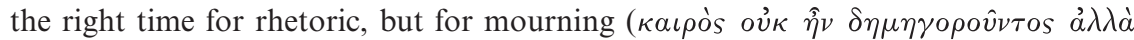
$\pi \epsilon \nu \theta 0 \hat{v} \tau \tau o s, 3.4 .5)$. As in the first speech, the power of rhetoric is neutralized, this time explicitly. Again, this neutralization is signposted by Chaereas' failure to achieve the aim envisaged by his public performance. After Theron's confession about Callirhoe's abduction, Chaereas asks that Theron's life should be spared in order to facilitate the search for Callirhoe (3.4.15). This request, however, is denied. The

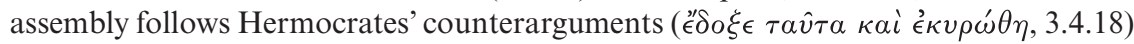
and Theron is executed.

In neither of the two speeches, then, is Chaereas capable of persuading his audience to grant his requests. A comparable lack of control over his narratee(s) characterizes his private speeches in the first half of the story. Moreover, in these dialogues, it is Chaereas himself who is systematically controlled by his interlocutors. In fact, many of his private speeches and dialogues suggest that Chaereas is 'easily misled', a characteristic explicitly attributed to him by the primary narrator in a

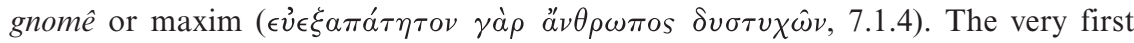
words uttered by Chaereas in the novel are emblematic of this characteristic. They form only one sentence and reproach Callirhoe for being responsible for traces of

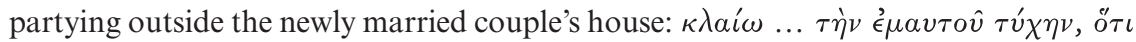

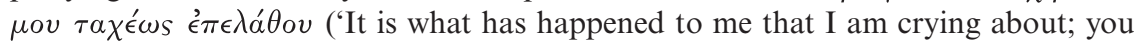
have forgotten me straightaway!', 1.3.5). These words are set in a highly emotional

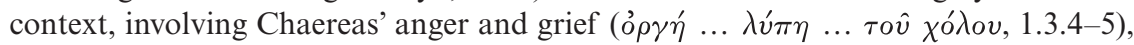
emphasized by the primary narrator's heavily elaborated account of Chaereas'

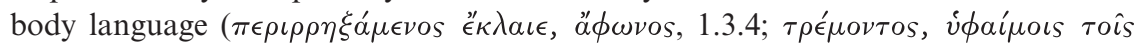
$\grave{o} \phi \theta \alpha \lambda \mu \circ \hat{\imath} \kappa \alpha i \pi \alpha \chi \epsilon \hat{\imath} \tau \hat{\omega} \phi \theta \dot{\epsilon} \gamma \mu \alpha \tau \iota, 1.3 .5)$. Unlike the protagonist himself, however, the reader has been informed by the primary narrator that Chaereas is being misled by

25 Smith (n. 4), 126. 
the suitors, who left evidence of a party at the house the night before in order to trigger Chaereas' anger and suspicion of his wife. In these circumstances, Chaereas very first word, $\kappa \lambda \alpha i \omega$ ('I cry') will turn out to be emblematic of his behaviour when confronted with misfortunes in the following six books of the novel. ${ }^{26}$

Chaereas' characterization as an object of deception by other characters is echoed in his depiction as an internal narratee in the first six books of the novel. From the very beginning of the novel, Chaereas is controlled and manipulated by other characters' speeches. A first example is the dialogue between Chaereas and the tyrant of Acragas' accomplice, who fools Chaereas into believing that his wife Callirhoe has been unfaithful (1.4.7-8). Chaereas is devastated by the news and asks his interlocutor to witness the adultery with his own eyes. This request plays, of course, precisely into the hands of the conspirators, and allows the interlocutor to set up the meeting between Chaereas and Callirhoe's alleged adulterer.

My second example of Chaereas as dupe is the conversation between Chaereas and Mithridates (4.4.2-5). This dialogue occurs when Chaereas has just been informed by Mithridates that Callirhoe has married Dionysius in Miletus. Chaereas asks Mithridates' permission to go to Miletus and claim his wife from Dionysius. Mithridates, however, advises against this plan and suggests that Chaereas write a letter to Callirhoe first. He prefaces his advice as follows:

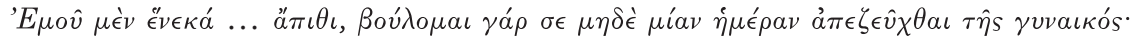

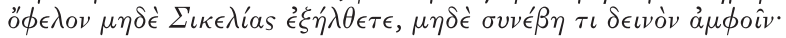

As far as I am concerned ... you can go. I don't want you to be separated from your wife even for one day. I wish that you had never left Sicily and that no trouble had ever befallen the two of you. ${ }^{27}$

The reader knows that Mithridates' words aim at fooling Chaereas into believing that he is truly concerned about Chaereas' love for Callirhoe. Unlike Chaereas, the reader has been informed shortly beforehand about Mithridates' hope that, while Dionysius and Chaereas quarrel about Callirhoe, he himself will be able to become her lover (4.4.1). The primary narrator explicitly clarifies this strategy when explaining why Mithridates rejoices in Chaereas' sad story: Chaereas' grief gives him the opportunity to talk and take action about Callirhoe 'in order that he would appear to be helping

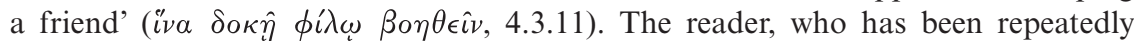
informed about Mithridates' love for Callirhoe (4.1.9, 4.2.4), realizes that Mithridates tries to profit from the situation at Chaereas' expense. Chaereas, on the other hand, has no idea about his host's plan and thinks that he truly wants to help him. In his letter to Callirhoe, he even calls Mithridates his 'benefactor' ( $\tau \dot{o} \nu$ '́ $\mu \grave{o} \nu \epsilon \dot{v} \epsilon \rho \gamma \epsilon ́ \tau \eta \nu$, 4.4.7). At the end of the story, when narrating his adventures in front of the Syracusan people, he equally characterizes Mithridates as a true helper ( $\dot{\alpha} \pi \circ \delta$ ôvvaı $\delta \epsilon \epsilon$

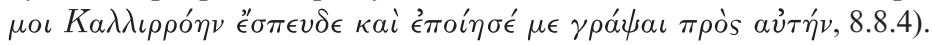

All the above speeches, both public and private, characterize Chaereas in a similar way. In public speech he is not able to persuade his audience to approve his requests. In private conversation his lack of control is highlighted by the control exerted upon

${ }^{26}$ Cf., e.g., Chariton, Callirhoe 1.6.5, 3.3.14, 3.4.4, 3.6.6, 4.4.6, 5.2.4. The contrast between the resourceful Greek novel heroines and their helpless male counterparts in general has been addressed by, among others, Konstan (n. 15 [1994]), 15-26.

27 English translations of Chariton's text are taken from B.P. Reardon (ed.), Collected Ancient Greek Novels (Berkeley/Los Angeles/London, 1989) and slightly modified where necessary. 
him by other characters. Let us now turn towards Chaereas' speeches after his character shift in the seventh book. His first words after this shift are emblematic of a new strand in his characterization. This speech, addressed to the leader of the Egyptian rebels, occurs when Chaereas and Polycharmus have been taken prisoner by

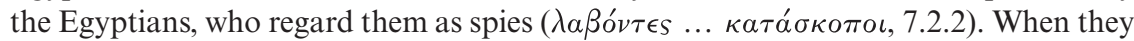
are brought before the leader, Chaereas, without waiting to be addressed, embarks on a speech in which he reminds the audience of his homeland and noble descent ( $\dot{\eta} \mu \epsilon \hat{s}$

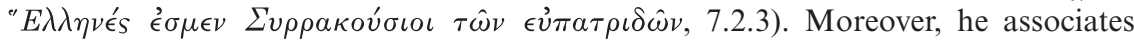
himself with the famous Hermocrates by mentioning his marriage to his daughter Callirhoe (7.2.3). S. Smith correctly identifies this speech as the first instance of Chaereas' participation in 'the same rhetoric of self-representation adopted by other Syracusans in the story', ${ }^{28}$ Chaereas relies on his ties to Hermocrates to secure a safe entrance into the Egyptian army. Ultimately, he expresses his and his friend's desire to die fighting against the Persians. Chaereas' attention to self-depiction is easily identifiable as a classical rhetorical technique, well documented by Aristotle's famous account of the importance of favourable character construction (êthos) as one of the tools ensuring the audience's persuasion. ${ }^{29}$ Significantly, Chaereas' rhetorical strategy is successful: the Egyptian leader welcomes them into the army and provides them with arms and a tent. In this speech, Chaereas exploits his own origins in order to achieve a specific aim and, simultaneously, takes rhetorical control over his narratee for the first time. By creating a favourable characterization of himself and his friend, he succeeds in becoming a soldier in the Egyptian army, thus effecting the plan suggested by Polycharmus earlier (7.1.11).

A study of Chaereas' remaining public speeches after his character shift corroborates and, simultaneously, develops this point about the protagonist's changing rhetorical abilities. In the following overview, I focus on a number of rhetorical techniques adopted by Chaereas. These observations will be contextualized by an account of how the primary narrator enhances his protagonist's characterization in these passages.

In a number of speeches Chaereas' characterization as a rhetorically successful soldier and general is constructed, both by the primary narrator and by Chaereas himself, through assimilation with mythological and historical paradigms. Chaereas' speech in the assembly of the Egyptian army generals (7.3.4-5) is a case in point. Since the impregnable city of Tyre is an obstacle to the Egyptian military advance, their leader proposes to retreat. At this proposal all are silent and downcast ( $\sigma \iota \omega \pi \dot{\eta}$

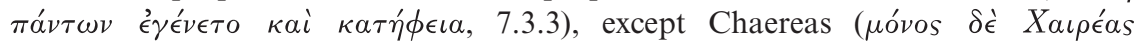

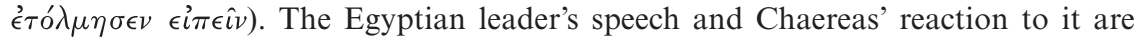
modelled on an episode in the ninth book of the Iliad (9.17-28 and 9.32-49), where Agamemnon's proposal to return to Greece is countered by Diomedes. This parallel is suggested by a number of elements. Like the Egyptian leader, Agamemnon apostro-

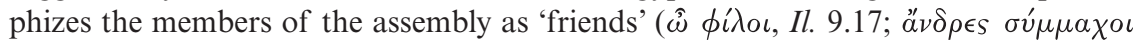

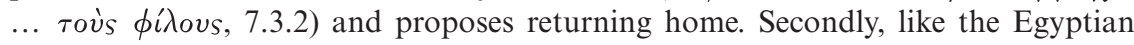
leader's speech, Agamemnon's speech triggers silence ( $\pi \alpha \dot{\alpha} \nu \tau \epsilon S \ldots \sigma \iota \omega \pi \hat{\eta}, I l .9 .29)$ and sadness $(\tau \epsilon \tau \iota \eta o ́ \tau \epsilon s, I l$. 9.30) in the audience. The reaction of the audience to Diomedes' speech, thirdly, coincides with the assembly's reaction to Chaereas' speech:

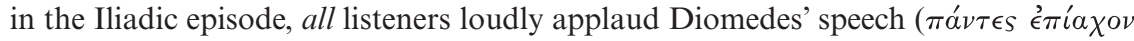

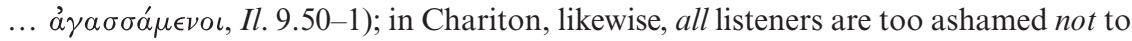




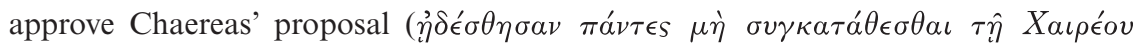
$\gamma \nu \omega \dot{\mu} \eta$, 7.3.6). Fourthly, and finally, Chaereas' answer itself unmistakably evokes Diomedes':

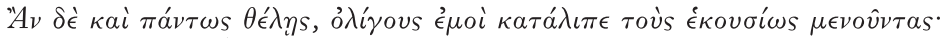

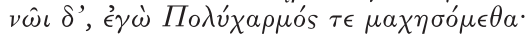

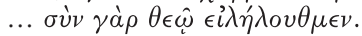

But if you insist on going, leave a few volunteers with me; I and Polycharmus will fight, for it is at a god's behest that we have come.

These words are an adaptation of the conclusion to Diomedes' speech (Il. 9.48-9). They evoke Diomedes' forecast about Agamemnon's plan to abandon the war: if Agamemnon wants to flee, the Greeks will remain. And if they want to flee as well, at least Diomedes himself and his companion Sthenelus will remain. ${ }^{30}$ It has often been noted that both explicit and implicit assimilation of Chaereas with epic heroes is frequent in Chariton. ${ }^{31}$ What is important in this passage, however, is that it is not merely the primary narrator who casts Chaereas as an epic hero, but also Chaereas himself, adopting the above-mentioned Homeric quotation in his own speech. ${ }^{32}$ Chaereas presents himself as an epic hero and soldier. This strategy is successful and Chaereas achieves his aim: the Egyptian leader abandons his plan to retreat and

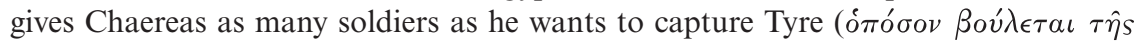
$\sigma \tau \rho \alpha \tau \iota \hat{\alpha} s$ '̇ $\pi \hat{\imath} \lambda \epsilon \kappa \tau o \nu \lambda \alpha \beta \epsilon \hat{\imath} \nu)$.

A similar pattern appears almost immediately afterwards, when Chaereas

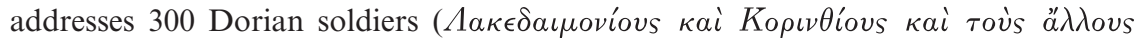
Пє capture Tyre (7.3.8-10). In this speech, which is an adaptation of the speech delivered by Xenophon to his men before they engage in battle against their Persian enemy (Xen. An. 3.2.7-32), ${ }^{33}$ Chaereas is once again assimilated with literary paradigms. Again, Chaereas assimilates himself with two famous heroes, Leonidas and Othryades, both, like Chaereas, leaders of 300 Spartans/Dorians at Thermopylae and

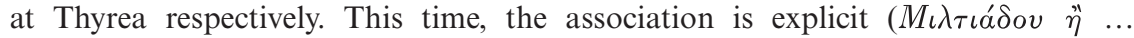
$\Lambda \epsilon \omega \nu$ íov, 7.3.11) and echoed by the result of Chaereas' speech, which is that his soldiers declare him their leader. Apart from assimilating himself with historical leaders, Chaereas adopts a number of other rhetorical techniques in order to pave the way for this decision. He starts, for example, by identifying his audience as 'the best

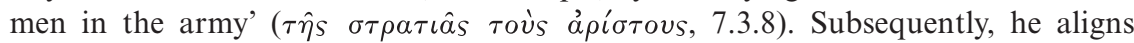
himself with his men by referring to their common virtues of $\epsilon \dot{v} \gamma \epsilon^{\prime} \nu \epsilon \iota \alpha$ and $\alpha \rho \epsilon \tau \eta^{\prime}$, and by contrasting himself and his audience with their Tyrian enemies. Finally, he does not propose that he himself should take command, but declares himself willing to serve under one of the 300 Greek soldiers.

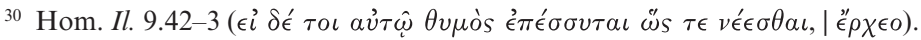

${ }^{31} \mathrm{Cf}$., among others, M. Biraud, 'L'hypotexte homérique et les rôles amoureux de Callirhoé dans le roman de Chariton', in A. Goursonnet (ed.), Sémiologie de l'amour dans les civilisations méditerranéennes (Paris, 1985), 21-7; P. Robiano, 'La citation poétique dans le roman érotique grec', REA 102 (2000), 509-29; E. Cueva, The Myths of Fiction. Studies in the Canonical Greek Novels (Ann Arbor, 2004), 24-5.

32 On characters' assimilation of themselves with mythological paradigms as a rhetorical device, cf. also Smith (n. 4), 104.

33 For details, cf. Smith (n. 4), 172-5. 
As well as assimilating himself with historical and mythological paradigms, Chaereas adopts other rhetorical techniques to persuade his audience. When, now as the admiral of the entire Egyptian fleet, he arrives with his army on Cyprus, he informs some of his troops that their Persian enemies have beaten the Egyptian land forces and killed their leader (8.2.10-11). The success of this speech, which is to persuade the soldiers to abandon the war and return home, is achieved mainly by two rhetorical techniques. First, the primary narrator emphasizes that Chaereas selects his internal narratees. His speech is not directed towards the entire army, but to his captains, the 300 Greek soldiers and 'all the Egyptians whom he saw to be well

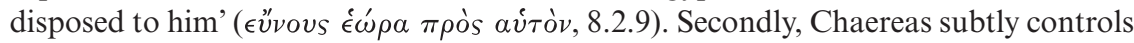
and manipulates his audience's decision-making process. Before depicting their hopeless military position and addressing the fact that they are surrounded by enemies

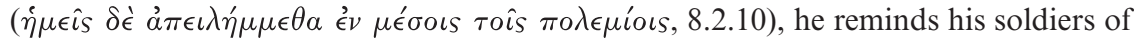
the importance of unity in their naval military successes up to that point (ópovoov $v \tau \epsilon S$ $\left.\dot{\epsilon}^{\prime} \kappa \alpha \tau \eta^{\prime} \sigma \alpha \mu \epsilon \nu \tau \hat{\eta} s \quad \theta \alpha \lambda \alpha ́ \sigma \sigma \eta s, 8.2 .10\right) .{ }^{34}$ Subsequently, he suggests capitulation to the Persian king as the only possible solution. His audience's refusal to agree does not come as a surprise, either to the reader or to Chaereas himself. At last one of the soldiers called Brasidas proposes to return to Sicily. While everyone applaudes this

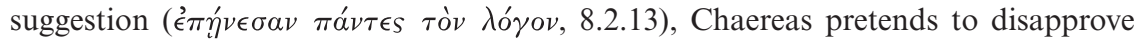

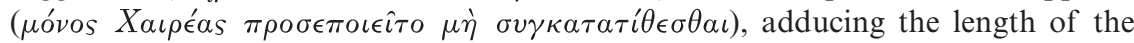
journey as a pretext ( $\left.\pi \rho \circ \phi \alpha \sigma \iota \zeta{ }^{\prime} \mu \epsilon \nu o s\right)$ for his scepticism. The primary narrator, for his part, informs the reader that Chaereas only wants to test the audience's firmness

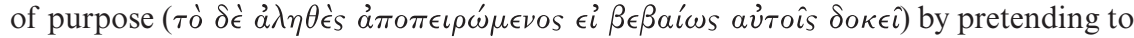
disagree. When the troops insist, Chaereas is 'persuaded' to go home. Thus, Chaereas reaches a consensus about terminating the war and returning home, without proposing this solution himself.

This episode is replete with Homeric resonances relevant to Chaereas' characterization. Chaereas' reaction to Brasidas' proposal clearly echoes Agamemnon's attempt to manipulate the army in Iliad $2.53-154 .{ }^{35}$ In this passage, Agamemnon proposes withdrawal from the war and urges the soldiers to return home ( $\phi \epsilon \dot{v} \gamma \omega \mu \epsilon \nu$ $\sigma \dot{v} \nu \nu \eta v \sigma i \phi^{\prime} \lambda \eta \nu$ 's $\pi \alpha \tau \rho i \delta \alpha$ yaiav, Il. 2.140). As announced by the primary narrator

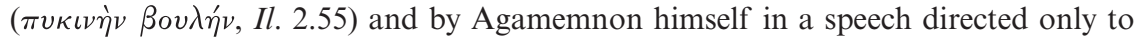
the members of the council (Il. 2.70-5), this is a ruse, ultimately intended to make the soldiers more eager to participate in a planned attack on Troy $\left(\dot{\alpha} \lambda \lambda^{\prime} \alpha^{\prime} \gamma \in \tau^{\prime} \alpha \iota^{\prime} \kappa \epsilon^{\prime} \nu \pi \omega s\right.$ $\theta \omega \rho \eta^{\prime} \xi o \mu \epsilon \nu$ vias 'A $\chi \propto \iota \hat{\omega} \nu$, Il. 2.72). Both in Homer and Chariton, then, the general's attempt to manipulate the army is designed to test the soldiers ( $\pi \epsilon \iota \rho \eta^{\prime} \sigma o \mu \alpha \iota, I l .2 .73$; $\dot{\alpha} \pi о \pi \epsilon \iota \rho \dot{\omega} \mu \epsilon \nu o s$, Chariton 8.2.13). The crucial difference between the two episodes is, of course, that Agamemnon's stratagem fails and results in chaos: the soldiers immediately run to the ships to prepare for departure. Significantly, order is not restored until Odysseus' rhetorical skills 'in a lordly manner brought the army under

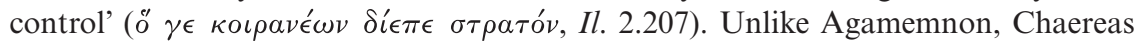
does not propose returning home, but subtly paves the way for this suggestion by proposing capitulation to the Persian king, well knowing that his audience will not agree. In both cases, the audiences agree with the proposal to return home, but whereas Agamemnon expects the opposite reaction from his troops, Chaereas' subtle

34 Cf. Smith (n. 4), 97.

35 The implicit presence of this Iliadic episode has been touched upon by G.P. Goold, Chariton. Callirhoe (Cambridge, MA/London, 1995), 375, and Smith (n. 4), 97, but has not been dealt with in any detail. 
demagoguery aims at triggering exactly this response. ${ }^{36}$ The Iliadic subtext in this episode, therefore, depicts Chaereas as a non-Agamemnon: whereas Agamemnon's testing of the soldiers unexpectedly results in chaos, Chaereas' testing of the soldiers triggers a confirmation of their resolution to go home, as anticipated by Chaereas. Whereas Agamemnon eventually needs Odysseus' rhetorical skills to restore order after his own unsuccessful rhetorical performance, Chaereas becomes an Odysseus himself in successfully manipulating his audience.

The episode involving Agamemnon's unsuccessful attempt to arm the soldiers for battle is not the only subtext underlying Chaereas' speech in Book 8 . The context in which the speech is set equally evokes the above-mentioned discussion between the Egyptian leader and Chaereas in the seventh book. This parallel is highlighted by the narrator's twofold explicit statement that Chaereas' reaction to the proposed

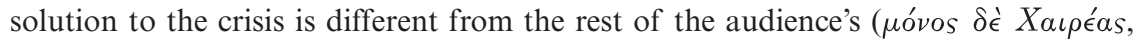

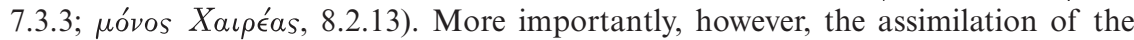
latter episode with the former reactivates the Iliadic episode of the disagreement between Agamemnon and Diomedes (Il. 9). In all three episodes, a military commander accentuates the army's hopeless position, after which the possibility is raised of abandoning the war and going home. Some verbal echoes underline the association between all three episodes. First, Chaereas' opening words echo the

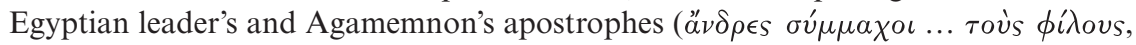

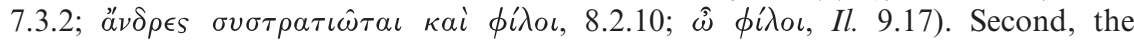
audience's reaction to Chaereas' speech about their hopeless position corresponds with the audience's reaction to the Egyptian commander's and Agamemnon's

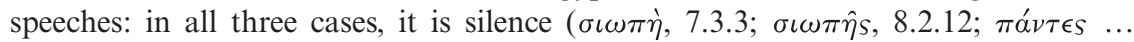
$\sigma \iota \omega \pi \hat{\eta}, I l$. 9.29). Third, Brasidas' speech, offering the solution to the problem that will eventually be chosen, is noted as being applauded by all listeners ( $\pi \alpha ́ v \tau \epsilon S, 8.2 .13$ ), which echoes the reception of Chaereas' and Diomedes' speeches in the two mirror

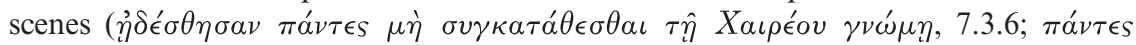

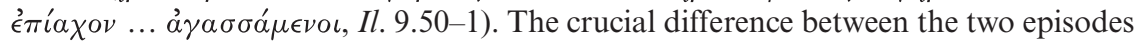
in Chariton, however, is that, whereas the first episode associates Chaereas with Diomedes, the second portrays Chaereas himself as the leader of the army who informs the troops about their hopeless military position. This role aligns him, of course, with Agamemnon. Moreover, the result of Chaereas' speech is, in the end, precisely the aim envisaged also by Agamemnon in Book 9, namely to abandon the war and return home. Significantly, the point of the association lies in the obvious difference between the two heroes: whereas Agamemnon's proposal is criticized and in the end rejected, Chaereas manages to achieve his aim. More interestingly, he does so without proposing this solution but by creating the illusion that he himself is being persuaded by a suggestion from the audience. Thus, he is able to engineer withdrawal from the war without running the risk of being characterized by his troops as a fool or a coward, two characteristics attributed to Agamemnon by Diomedes because of his proposal to withdraw. ${ }^{37}$ Like the echoes from Iliad 2, the echoes from Iliad 9 also depict Chaereas as a non-Agamemnon. Unlike Agamemnon, Chaereas controls his listeners by giving them the impression that they are in control themselves. Whereas

36 On Chaereas' characterization as a demagogue in this passage, cf. also Smith (n. 4), 98, who describes Chaereas as 'a kind of Cleon or Alcibiades, using subtle rhetorical persuasion as a means of demagoguery'.

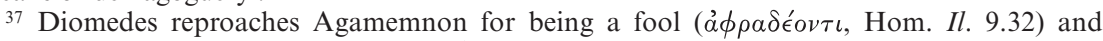
displaying a lack of courage $\left(\dot{\alpha} \lambda \kappa \dot{\eta} \nu \delta^{\prime}\right.$ ö $\tau o \iota \delta \hat{\omega} \kappa \epsilon \nu$, Il. 9.39). 
Chaereas himself was controlled by interlocutors in the first half of the story, he has become a public speaker whose rhetorical qualities surpass those of one of his most important epic paradigms.

A fourth rhetorical technique adopted by Chaereas to control his audience is distortion of the truth. In his speech addressed to the Tyrians (7.4.5), he uses a lie which eventually leads to the capture of Tyre. He and his soldiers approach the city gates and tell the Tyrians that they are mercenaries deserting the Egyptian army. The stratagem is successful: after the Tyrians have opened the gates, Chaereas and his troops take the allegedly impregnable city. It is worthwhile pointing out that earlier in the story, the protagonist uses a similar lie to gain access to the ranks of the Persian army (7.2.1). In order to cross the Euphrates in the Persians' wake, he and Polycharmus had claimed that they wanted to join the army. Unlike the Persians, the reader knew that this was a lie, since the two friends wanted to cross the river to join not the Persian but the Egyptian army. From the capture of Tyre onwards, the tactful use of lies and incorrect information will increasingly become part of the protagonist's rhetorical strategy. Chaereas' public speech in 8.2 .5 provides an excellent example. It occurs when Chaereas, who has become admiral of the entire Egyptian fleet, has been informed by a messenger of the defeat of the Egyptian land forces and the death of their leader. The messenger states, moreover, that the Persian enemy is on its way to Aradus, the island harbouring Chaereas' fleet. The primary narrator explicitly refers to Chaereas' subsequent speech to the Egyptian sailors as a ruse or $\tau \epsilon^{\prime} \chi \nu \eta$ (8.2.5): Chaereas tells the sailors that the Egyptian army has defeated the Persians, and orders them to set sail without specifying their destination. Interestingly, Chaereas' use of this scheme results from Callirhoe's intervention. When Chaereas leaps up after hearing the bad news, Callirhoe advises him not to make it public (8.2.4). She argues that this would cause revolt among the troops and that 'we

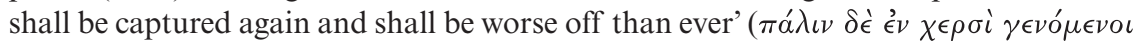

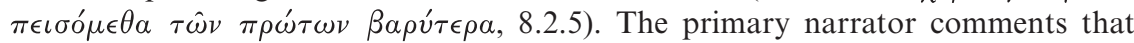
Chaereas is soon convinced by this advice ( $\tau \alpha \chi \epsilon^{\prime} \omega s \quad \dot{\epsilon} \pi \epsilon \dot{\prime} \sigma \theta \eta \tau \hat{\eta} \sigma v \mu \beta o v \lambda \hat{\eta}, 8.2 .5$ ). In Callirhoe's words, the issue of controlling and being controlled is explicitly highlighted as the main reason why Chaereas should not give an accurate account of what has happened. After his speech, as all the sailors are preparing to depart, Chaereas takes advantage of the confusion in the harbour ( $\beta$ ôs $\kappa \alpha i \tau \alpha \rho \alpha \chi \hat{\eta} s$ o $\left.\lambda \iota \mu \dot{\eta} \nu \pi \epsilon \pi \lambda \eta^{\prime} \rho \omega \tau o, 8.2 .7\right)$ to order his captains to set sail for Cyprus secretly. Once they arrive at Paphos the next day, they are safe from immediate danger. Thus Chaereas' public address to the naval troops clearly generates the desired effect: thanks to the $\tau \epsilon^{\prime} \chi \nu \eta$, Chaereas restrains his troops from mutiny and manages to keep them under control. Callirhoe has taught him that control over others can be achieved by rhetorical devices involving distortion of the truth.

Chaereas' last public speech (8.7.9-8.11) thematizes some important issues of manipulation and distortion of the truth already present in earlier speeches. Significantly this speech, in which Chaereas reports his adventures to the Syracusan people upon his homecoming, constitutes Chaereas' new identity before his fellow Syracusans. ${ }^{38}$ The narrator gives some important background information about this speech. First, it is not Chaereas who insists on telling the story, but the Syracusan crowd who

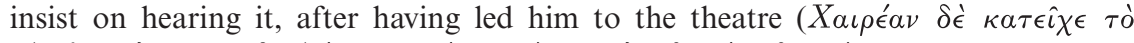

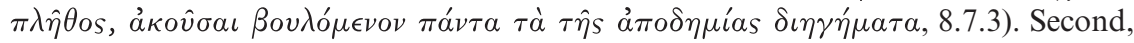


Chaereas starts with the last events of his story (ámò $\tau \hat{\omega} \nu \tau \epsilon \lambda \epsilon v \tau \alpha i \omega \nu, 8.7 .3)$ because 'he did not want to cause the people sorrow by telling them of the grim episodes at the beginning'. When the crowd protests, however, insisting that he does not omit

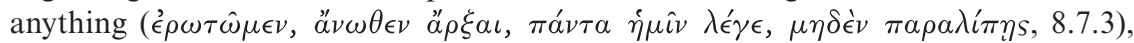
Chaereas hesitates because he is 'ashamed to talk about many events that had not

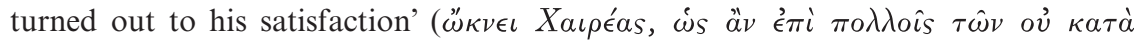

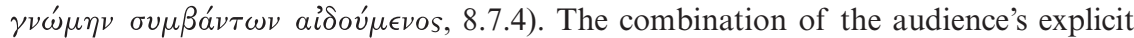
request not to omit anything and the narrator's equally explicit statement about Chaereas' hesitation must surely alert the reader as to whether the information provided in Chaereas' speech is actually complete. ${ }^{39} \mathrm{~S}$. Smith, moreover, has recently drawn attention to various sorts of deceptions and conceits in the scene when Chaereas returns to Syracuse. This scene, reminiscent of Alcibiades' triumphant return to Athens after exile, is filled with elements that consistently trigger incorrect inferences from the Syracusan people about what is happening. ${ }^{40}$ The issue of deception activated by these elements provides the framework in which Chaereas' speech should be read. I argue that Chaereas' account of his adventures is in some instances manipulatory and deceptive, diverging significantly from the primary narrator's account in the foregoing chapters of the novel.

The first relevant passage in Chaereas' speech is his account of his and Polycharmus' discovery of Callirhoe's statue in the temple upon their arrival in Miletus:

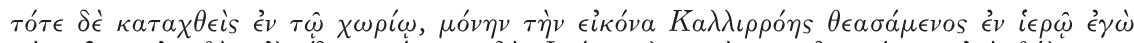

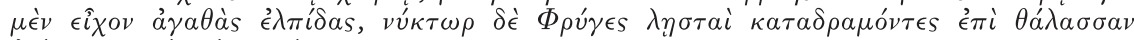
$\dot{\epsilon} \nu \epsilon ́ \pi \rho \eta \sigma \alpha \nu \mu \dot{\epsilon} \nu \tau \dot{\eta} \nu \tau \rho \iota \dot{\eta} \rho \eta \ldots$

At the time, when I had landed on this estate, I saw only Callirhoe's statue in a temple, and that gave me great confidence. But during the night a band of Phrygian brigands made a lightning raid on the shore, set fire to our ship ...

Chaereas contrasts the unfortunate outcome of the episode, due to the brigands' attack, with his own confidence in a good outcome after having seen Callirhoe's statue. The reader, however, recalls that Chaereas did not have 'great confidence' in this episode. In fact Chaereas fainted when he saw the statue of his wife, a reaction emphatically marked with a Homeric quotation by the primary narrator (3.6.3). The temple servant even had to bring water to resuscitate him. Moreover, the primary narrator emphasized Chaereas' lack of self-control in this episode by contrasting the protagonist with his friend Polycharmus, who was able to control himself ( $\sigma \omega \phi \rho o \nu \hat{\omega} \nu$, 3.6.5) and prevented Chaereas from betraying who they were (ov Bovió $\mu \epsilon v o s$

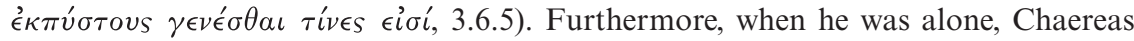
threw himself on the floor and deplored his situation in a lamenting monologue. In short, the reader recalling this episode while reading Chaereas' report realizes that 'great confidence' is not a correct representation of what had happened. Chaereas, however, understandably chooses to omit his lack of self-control in his version of the story.

As to why Callirhoe married Dionysius, Chaereas says the following:

${ }^{39}$ On checking a character's direct speech against the primary narrator's account, cf. T. Hägg, Narrative Technique in Ancient Greek Romances. Studies of Chariton, Xenophon Ephesius, and Achilles Tatius (Stockholm, 1971), 253.

${ }^{40}$ Smith (n. 4), 231. 


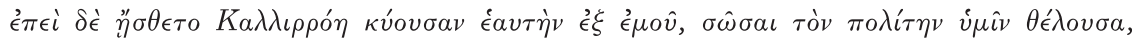

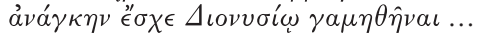

When Callirhoe realized that she was pregnant by me, she found herself compelled to marry Dionysius, because she wanted to preserve your fellow citizen.

That Callirhoe is compelled to marry Dionysius, is, indeed, confirmed by the primary narrator, who likewise adopts the term á $\nu \alpha ́ \gamma \kappa \eta(5.1 .1)$ to refer to Callirhoe's marriage. Chaereas is equally correct in adducing his child as the reason for Callirhoe's decision to marry. The antonomasia used to refer to the child, however, is significant. By calling his child $\tau \dot{o} \nu \pi o \lambda i ́ \tau \eta \nu$ v $\mu \hat{\imath} \nu$, Chaereas seems to be suggesting that Callirhoe's loyalty towards her home city played a role in this decision, ${ }^{41}$ which was not the case according to the primary narrator's version. Chaereas thus colours his story in order to generate the audience's sympathy for his wife.

Chaereas' desire to generate sympathy for his wife might be responsible for the distortion of some other details of the 'true story'. In his account of his imprisonment on Mithridates' estate, he states that Mithridates discovered his identity after

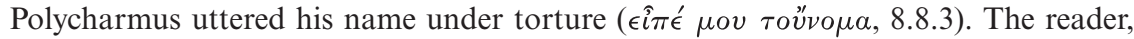
however, recalls that Polycharmus did not utter Chaereas' name, but Callirhoe's and that he did so not under torture, but when Polycharmus and Chaereas were carrying their crosses to the execution site. Moreover, Polycharmus' utterance was a fierce reproach:

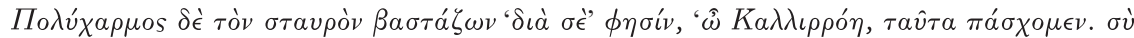

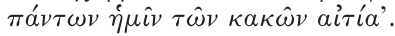

Polycharmus, as he carried his cross, said: 'Callirhoe, it is because of you that we are suffering like this! You are the cause of all our troubles!'

To mention this detail in front of the entire Syracusan people would be embarrassing both for Chaereas' friend Polycharmus and for his wife Callirhoe. It is therefore reasonable to assume that Chaereas decides to omit this detail in the 'official' version.

Chaereas' account of the events is also characterized by a tendency to emphasize the hero's own achievements at the expense of the achievements of other characters. He recounts his arrival amongst the Egyptian army, for example, as follows:

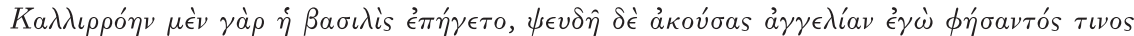

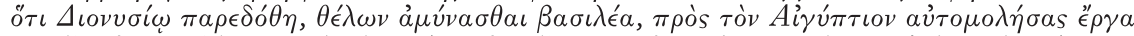

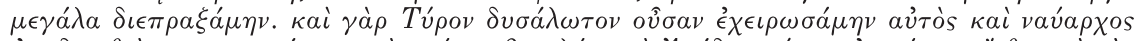

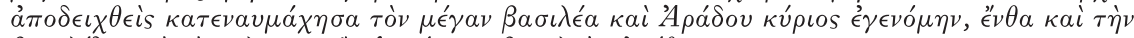

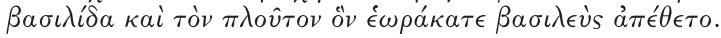

The Queen took Callirhoe with her, and I heard a false report - someone told me she had been awarded to Dionysius. To get my revenge on the King I went over to the Egyptians and brought off great feats: by my own actions I subdued Tyre, which was very difficult to take; I was then appointed admiral, beat the Great King at sea, and captured Aradus, where the King had left the Queen for safety, along with the riches you have seen.

The emphasis laid by Chaereas upon his own achievements is significant. Accordingly, he completely omits the role played by Polycharmus in this important episode. As the reader recalls, Chaereas burst into a lament and wanted to commit suicide after hearing the false report of Callirhoe that he presents here as the starting point of his

${ }^{41}$ See also Smith (n. 4), 223. 
personal aristeia (7.1.4-7). It was Polycharmus who came up with the idea of harming their enemy with their own death. Again, Chaereas subtly adapts an episode which reveals his embarrassing lack of self-control. Instead of telling the truth, he credits himself with the decision to join the Egyptian army and immediately proceeds with recounting his own $\epsilon^{\prime} \rho \gamma \alpha \mu \epsilon \gamma \alpha \dot{\lambda} \lambda$.

This pattern is repeated in the protagonist's account of how he managed to secure the Persian king's friendship for the Syracusan people:

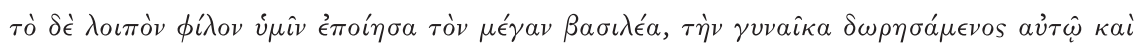

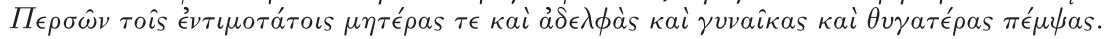

(8.8.10)

Finally, I secured the Great King's friendship for you by making a present to him of his wife and by sending to the Persian nobles their mothers and sisters and wives and daughters.

At this point, the reader vividly recalls that it was Callirhoe's idea, not Chaereas', to release the Persian queen (8.3.1). Significantly, Chaereas had been blushing while admitting to his wife that he wanted to take the queen to Syracuse as a slave (8.3.1). ${ }^{42}$ Moreover, in his letter to Artaxerxes, Chaereas did admit that it was not his but

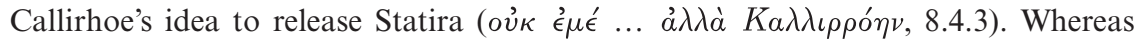
Chaereas presents the king's friendship for Syracuse as his personal achievement, the reader realizes that there would not be any such friendship if Callirhoe had not intervened. In fact, the idea of keeping the Persian queen as a prisoner had explicitly been referred to as madness by Callirhoe ( $\left.\mu \alpha v^{\prime} \alpha \nu, 8.3 .2\right)$. Again, Chaereas credits himself with someone else's achievements.

This analysis explains why Chaereas at first is not willing to recount his adventures. The story contains a number of episodes about which he should rightly be ashamed. It is significant that, by the end of the novel, Chaereas is capable of distorting and covering up these episodes. It is equally worthwhile to note that, after his speech, his request that his sister be given in marriage to Polycharmus is accepted. Unlike in his two speeches to the Syracusans at the beginning of the story, Chaereas has become an orator who is able to control his audience.

\section{CONCLUSION}

The above observations about Chaereas' changing rhetorical ability lead me to suggest that the strand of self-control in the protagonist's characterization acknowledged by D. Scourfield ${ }^{43}$ can be complemented by the acknowledgment of an equally important strand of rhetorical control over other people. In addition to the transition from lacking self-control to adopting self-control in mastering anger, Chaereas' character displays a significant transition on the level of rhetorical performance. At the beginning of the story, Chaereas is unable to achieve his desired aims through the use of speech. He lacks the rhetorical control required to persuade his audience. Moreover, in private conversation, he is controlled, and even manipulated and deceived, by his interlocutors. From the seventh book onwards, however, he develops the rhetorical ability to persuade his audience through the manipulation of speech. This ability is reflected in various features. First, he is successful in constructing favourable characterizations of himself to ensure his audiences' persuasion, a

${ }^{42}$ On the significance of blushing in Chariton (and this scene in particular), see De Temmerman (n. 11), 235-52, at 247-8. 
traditional rhetorical device discussed by Aristotle as the construction of êthos. Second, Chaereas associates himself, explicitly and implicitly, with mythological (epic) and historical heroes to enhance this construction (e.g. 7.3.4-5 and 7.3.8-10). Third, he is aware of the importance of consciously selecting his internal narratees (e.g. 8.2.10-11). A fourth technique consists in subtly manipulating his audience by guiding his listeners towards a specific decision while giving the impression that they have freely and independently reached it (e.g. 7.3.8-10 and 8.2.10-11). Fifth and finally, Chaereas realizes the importance of distorting the truth to achieve control over his audience. The assumption that rhetorical control involves conveying information that does not necessarily correspond to reality underlies all his public speeches from the capture of Tyre onwards. It is this last technique in particular that culminates in his last public speech addressed to the Syracusan people. His account of his and Callirhoe's adventures is greatly concerned to cover up embarrassing details of the story. By omitting details compromising his own behaviour and by crediting himself with other persons' achievements, Chaereas characterizes himself more favourably than the primary narrator does in the foregoing story.

Why does the narrator depict this development in his hero's rhetorical abilities in the later books of the novel? First, my observations are in line with, and offer an interesting addition to, S. Smith's recently developed argument that Chariton's novel implicitly tells a story about the transition of political leadership from Hermocrates to Chaereas. ${ }^{44}$ Within such a transition, the achievement of rhetorical control is, as I have pointed out, of crucial importance. From a broader perspective, my reading of Chaereas deepens S. Lalanne's thesis that the ancient Greek novels embody the protagonists' rite of passage from childhood to mature adulthood..$^{45}$ In her view, the heroes' and heroines' many ordeals and adventures function as preparations for their tasks as socially accepted citizens and wives respectively. ${ }^{46}$ For male characters, this paideia is primarily directed towards the acquisition of a number of basic qualities such as moderation, perseverance and magnanimity, which are emblematic of the virtues of a civilized Greek male adult. In the case of Chaereas I argue that Chariton thematizes the importance of rhetorical skilfulness as yet another essential quality of male adulthood. ${ }^{47}$ In addition to the military achievements marking Chaereas' entry into manhood from Book 7 onwards, his ability to perform successfully on the battlefield of rhetoric is at least as important. It is no coincidence, therefore, that Chaereas' first active resistance against the misfortunes befalling him occurs in the Babylonian courtroom during the trial regarding the validity of his and Dionysius' claims to Callirhoe. Although his intervention in this case is limited to the interjection of brief reproaches to Dionysius and a number of arguments corroborating his claim (5.8.5), its rhetorical setting is proleptic of the important place that rhetoric will occupy in Chaereas' life once he decides to take control of his own destiny. Moreover, Chariton's

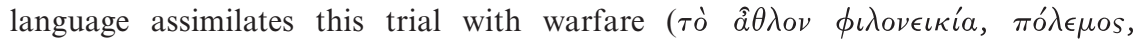
$\mu \alpha \chi o ́ \mu \epsilon \nu \iota),{ }^{48}$ thus implicitly marking Chaereas' first attempt to intervene actively in

43 Scourfield (n. 18), 163-84, at 163-75.

44 Smith (n. 4), 190-1.

45 Lalanne (n. 20).

46 See Lalanne (n. 20), 16.

47 See also R. Webb, 'Rhetoric and the novel: sex, lies and sophistic', in I. Worthington (ed.), $A$ Companion to Greek Rhetoric (Malden, MA/Oxford/Carlton, 2007), 526-41, at 534, who touches upon the link between rhetoric and masculinity in Chaereas' last speech in Syracuse (8.7.9-8.11).

48 Lalanne (n. 20), 16. 
the course of events as an emblem of two major areas in which he will excel in the succeeding books.

The above discussion provides a dimension to the characterization of Chariton's male protagonist that has remained relatively unexplored so far. First, Chaereas' characterization cannot be adequately described by merely addressing the notion of typical character. Rather, it requires attention to specific aspects of individualization. Second, his characterization does not merely thematize the oft-noted transition from helplessness and weakness to courage and strength, but seems to suggest that, like self-control, the ability to control other people by the power of rhetoric is an essential tool to be acquired on the road towards male adulthood. This suggests that Chariton's male protagonist does not fit into the clear-cut and somewhat monolithic view developed recently on male protagonists in the novels as lacking rhetorical skills altogether. ${ }^{49}$ Third, I think that Chaereas' characterization has a much more realistic dimension than has been identified by existing scholarship. In Chariton, becoming an adult male citizen involves developing awareness of the importance of rhetorical control, manipulation and deception, all abilities that display a much closer relationship to psychological realism than to idealism. The widely held view that Chariton's Chaereas is the prototype of the 'ideal' novel hero should therefore be revised. Instead, it seems to me more plausible that Chariton consciously develops a critical stance towards idealistic character depiction in the novelistic genre. Therefore, ultimately, I do not believe that the widely adopted classification of ancient novelistic texts into ideal and realistic texts allows us to capture the peculiar position of Chariton's novel. ${ }^{50}$

Ghent University

KOEN DE TEMMERMAN

koen.detemmerman@ugent.be

${ }^{49} \mathrm{~K}$. Haynes, 'Power of the prude: configurations of the feminine in the Greek novel', Ancient Narrative 1 (2001), 73-92, for example, highlights novelistic heroines' rhetorical qualities in contrast with the lack of such qualities in their male counterparts. In Fashioning the Feminine in the Greek Novel (London, 2003), she develops this point at greater length.

${ }_{50}$ An earlier version of this paper was presented in a Kyknos panel on the ancient novel at the Celtic Conference in Classics at the University of Wales, Lampeter (August-September 2006). I would like to thank Anton Powell for the conference organization, John Morgan and Meriel Jones for the organization of the panel, the audience for their comments, and Kristoffel Demoen, Graeme Miles, Susan Stephens and the anonymous referee of $C Q$ for suggestions on written versions. Any errors or oversights are entirely my own. 